\title{
Growth Performance and Ruminal Metabolic Variables of Goats Fed Rain Tree (Samanea saman) Pods
}

\author{
M. J. Morais ${ }^{a}$, C. C. Sevillaa ${ }^{a}$, J. T. Dizon ${ }^{b}$, G. L. Manulatc, E. E. C. Abes ${ }^{c}$, \& A. A. Angeles ${ }^{a, c, *}$ \\ anstitute of Animal Science, College of Agriculture and Food Sciences, University of the Philippines Los Baños, \\ College, Laguna 4031 \\ ${ }^{b}$ College of Public Affairs and Development, Domingo Lantican Avenue, University of the Philippines Los Baños, \\ College, Laguna 4031 \\ ${ }^{\mathrm{c}}$ Dairy Training and Research Institute, College of Agriculture and Food Sciences, University of the Philippines \\ Los Baños, College, Laguna 4031 \\ *Email of corresponding author: aaangeles8@up.edu.ph \\ (Received 05-12-2017; Reviewed 22-12-2017; Accepted 18-01-2018)
}

\begin{abstract}
The effect of rain tree pods (RTP) or acacia pods on the growth performance, rumen metabolites, and digestibility of dry matter (DM) and crude protein (CP) in goats was evaluated through feeding trial and in situ methods. Eighteen 7 month-old Philippine native goats with body weight range of $7.86 \pm 1.28 \mathrm{~kg}$ were divided into three groups consisting of six replicates and randomly assigned to one of treatment diets containing $0 \%, 50 \%$, and $100 \%$ RTP in the concentrate portion of a ration containing $65 \%$ roughage and $35 \%$ concentrate. Three rumen-cannulated mature goats were used in the in situ studies to determine the dietary effects on rumen fluid $\mathrm{pH}$, total volatile fatty acids (VFA), ammonia, and rumen DM and CP digestibilities. Differences $(P$ values $<0.05)$ were observed on daily gain, total feed intake, and feed efficiency with diets having $>50 \%$ RTP generally resulted in lower above-stated performance parameters. Rumen fluid $\mathrm{pH}$ of goats decreased after feeding and was lowest in goats fed with $50 \%$ RTP. Concentrations of VFA and ammonia were not significantly different. Slowly degradable DM of the test diets were higher in concentrate mixture without RTP. Degradable fractions of CP had highest value on concentrate mixture without RTP while lowest on $100 \%$ RTP. However, no differences were observed on potentially digestible fractions and degradability constants of DM and CP. It could be concluded that RTPs can be an alternative ingredient in concentrate mixtures given up to $50 \%$ in the mixture as part of a daily ration for goats.
\end{abstract}

Keywords: acacia pods, alternative feed source, legumes, nutrient evaluation

\section{INTRODUCTION}

Feeding and nutrition are limiting factors in ruminant production in tropical and subtropical regions due to the inconsistent supply and variable nutrient values of forage and browse species caused by fluctuating rainy and dry seasons. Forage, trees, and shrubs are inexhaustible nutrient source which greatly contributes to the improvement of an animal diet and therefore, could reduce the use of concentrates feeds (Delgado et al., 2014). Goat production in Asia are predominantly operated by small-hold farmers. Raising goats requires lower capital investment and production costs. In addition, it is a good source of protein for household consumption for resource-poor communities.

It is recommended that ruminant production models should be based on the vegetation on a particular area minimizing dependence on external inputs with particular focus on fodder trees (Olivares et al., 2013, Rojas et al., 2012). There has been an increasing interest in the utilization of unconventional feed sources that could supply for the shortage of roughages and feeds (Nyamukanza et al., 2008). Among the unconventional feed sources is the rain tree (Samanea saman) pods which is being considered as a potential source for animal feeds. The rain tree is a multipurpose tree often planted in parks and pastures, vacant lots, churches, and school grounds as well as in the roadsides and planned landscapes (Hagan et al., 2016). In Asia, rain tree provides green fodder supplement for goats, sheep, and cattle. The sweet pulp of the pods was observed to be eagerly eaten by cattle, hogs, horses, and goats (Staples \& Elevitch, 2006). The rain tree has two flowering seasons which are during the months of February to May and September to November (Hagan et al., 2016). An average of 200-250 kg of pods can be harvested from a mature tree after the flowering season which is roughly 500-600 $\mathrm{kg}$ of pods annually (Rath et al., 2014).

Rain tree pods make an excellent feed supplement for livestock. It contains approximately $13.0 \%$ to $18.1 \%$ crude protein, $18.2 \%$ total sugar, $8.4 \%$ sucrose, and $4.0 \%$ condensed tannins, which makes it a potential feed for 
improving rumen function and improving ruminant productive performance as a whole (Flores, 2002; Staples \& Elevitch, 2006). When utilizing an unconventional feed source such as rain tree pods (RTPs), it is important to conduct an evaluation on the nutrient composition, digestibility parameters, and its effect on the productive performance of an animal (Berhan \& Getachew, 2009; Kumara-Mahipala et al., 2009; Mokoboki et al., 2011). This study aimed to determine the dietary effects of rain tree pods on the growth performance, rumen metabolites, dry matter, and crude protein digestibility of Philippine native goats (Capra hircus Linn).

\section{MATERIALS AND METHODS}

\section{Experimental Design}

Nine male and nine female Philippine native growing goats at seven months of age with an average body weight of $7.86 \pm 1.28 \mathrm{~kg}$ were used in the feeding trial. The goats were kept in holding crates and fed ad libitum roughage and concentrates with or without rain tree pods (RTPs). The basal feed was composed of Napier grass (Pennisetum purpureum) harvested at 45 days. The goats were randomly allotted into three treatment groups following a completely randomized design. The treatments consisted of Napier grass and a concentrate mixture of rice bran, copra meal, and RTPs. The concentrate mixtures were formulated to contain $0 \%$ RTPs (Treatment 1), 50\% RTPs (Treatment 2), and 100\% RTPs (Treatment 3). The percent inclusion of RTPs in a concentrate mix was presented in Table 1 along with the calculated analysis in DM basis.

\section{Preparation of Experimental Diets}

Mature rain tree pods (RTPs) were used in this study. Fallen RTPs were hand-picked within the campus of the University of the Philippines Los Baños and chopped to about 2-2.5 cm. These chopped RTPs were then dried and ground to pass $2 \mathrm{~mm}$ screen. Ground RTPs were mixed with rice bran and copra meal to constitute the dietary treatments. The chemical compo-

Table 1. Ration composition and nutrient content of rain tree pods (RTP) concentrate mixtures in DM basis

\begin{tabular}{lccc}
\hline \multirow{2}{*}{ Ingredients } & \multicolumn{3}{c}{$\%$ DM, Concentrate mixtures } \\
\cline { 2 - 4 } & $0 \%$ RTP & $50 \%$ RTP & $100 \%$ RTP \\
\hline Rain tree pods & 0 & 50 & 100 \\
Rice bran & 70 & 35 & 0 \\
Copra meal & 30 & 15 & 0 \\
$\quad$ Total & 100 & 100 & 100 \\
Nutrient content (\%) & & & \\
$\quad$ Dry matter & 91.62 & 91.62 & 91.61 \\
Ash & 9.28 & 6.77 & 4.26 \\
Crude protein & 14.13 & 14.33 & 14.54 \\
Crude fiber & 14.02 & 21.09 & 28.14 \\
Crude fat & 14.09 & 8.42 & 2.75 \\
$\quad$ Nitrogen-free extract & 34.51 & 38.21 & 41.92 \\
\hline
\end{tabular}

sition of the feed ingredients used in each concentrate mixtures is presented in Table 2 .

\section{Feeding System}

The goats in all treatments were allowed free access to water, roughage, and concentrates. The animals were fed a ration of $65 \%$ forage and $35 \%$ concentrate mixtures at $3 \%$ of the live weight on dry matter (DM) basis. The experimental goats were also supplemented with mineral block (Phos-rich rockies) containing: Sodium (Na) 20\%, Calcium (Ca) 8.5\%, Magnesium (Mg) 0.5\%, Iodine (I) $300 \mathrm{mg} / \mathrm{kg}$, Selenium (Se) $10 \mathrm{mg} / \mathrm{kg}$, Manganese (Mn) $2500 \mathrm{mg} / \mathrm{kg}$, Ash 86\%, Phosphorus (P) 10\%, Iron (Fe) $0.3 \%$, Cobalt (Co) $50 \mathrm{mg} / \mathrm{kg}$, and Zinc (Zn) $300 \mathrm{mg} / \mathrm{kg}$.

Daily feed offered and refused were recorded. Samples of feed offered and refused were analyzed for $\mathrm{DM}$, crude protein $(\mathrm{CP})$, and fiber fractions as described in AOAC (2005); Van Soest \& Robertson (1985); and Isah \& Babyemi (2010). Voluntary intake was estimated by the difference between the feed offered and refused. Changes in weight of experimental goats were monitored every 14 days.

\section{Collection of Ruminal Contents}

Three rumen-cannulated goats were fed with Napier grass and RTP concentrate mixtures (0\% RTP, $50 \%$ RTP and $100 \%$ RTP) at $3 \%$ of the live weight on DM basis following a $3 \times 3$ Latin Square Design. For each sampling period, rumen digesta was obtained manually from various sites within the rumen and then filtered through three layers of cheesecloth to obtain rumen fluid. Rumen $\mathrm{pH}$ was measured before and three hours after feeding. Rumen $\mathrm{pH}$ was determined using a portable $\mathrm{pH}$ meter. $100 \mathrm{~mL}$ of rumen fluid samples collected after feeding were preserved with $1 \mathrm{~mL}$ of a $10 \%$ $(\mathrm{m} / \mathrm{v}) \mathrm{NaOH}$ solution or $1 \mathrm{~mL}$ of a $50 \% \mathrm{H}_{2} \mathrm{SO}_{4}$ solutions for rumen ammonia nitrogen $\left(\mathrm{NH}_{3}\right)$ concentration and total volatile fatty acid (VFA) analysis, respectively, as described by Holtshausen et al. (2000).

Ammonia-nitrogen $\left(\mathrm{NH}_{3}-\mathrm{N}\right)$ concentration was measured using an ammonia electrode (Model 95-12) in conjunction with an Orion Ion Analyzer (Model 501 pH/ $\mathrm{mV}$ meter $)$. Rumen fluid was made alkaline $(\mathrm{pH}>11)$ by the addition of $1 \mathrm{~mL}$ of $10 \mathrm{M} \mathrm{NaOH}$ per $100 \mathrm{~mL}$ sample. The sample ammonia nitrogen concentration was deter-

Table 2. Proximate chemical composition of feed ingredients (DM basis)

\begin{tabular}{lcccc}
\hline \multirow{2}{*}{$\begin{array}{l}\text { Chemical } \\
\text { composition }\end{array}$} & $\begin{array}{c}\text { Rain tree } \\
\text { pods }\end{array}$ & Rice bran & $\begin{array}{c}\text { Copra } \\
\text { meal }\end{array}$ & $\begin{array}{c}\text { Napier } \\
\text { grass }\end{array}$ \\
\cline { 2 - 5 } Dry matter (\%) & 91.61 & 91.47 & 91.97 & 12.76 \\
Ash (\%) & 4.26 & 10.09 & 7.38 & 20.61 \\
Crude protein (\%) & 14.54 & 12.69 & 17.48 & 14.97 \\
Crude fiber (\%) & 28.14 & 13.99 & 14.1 & 33.78 \\
Crude fat (\%) & 2.75 & 15.58 & 10.6 & 3.53 \\
$\begin{array}{l}\text { Nitrogen-free extract } \\
\text { (\%) }\end{array}$ & 41.92 & 31.12 & 42.41 & 60.13
\end{tabular}


mined from a calibration curve obtained using standard solutions of ammonium chloride.

Total VFA was measured by steam distillation and titration of the distillate. Two $\mathrm{mL}$ of $\mathrm{H}_{2} \mathrm{SO} 4 / \mathrm{MgSO}_{4}$ solution was added to $5 \mathrm{~mL}$ of rumen fluid and immediately followed by distillation process. The distillate was collected into a 250-mL conical flask, and generally 150-200 $\mathrm{mL}$ distillate was generated in $20 \mathrm{~min}$. A few drops of phenolphthalein indicator solution were added to the distillate and titrated against $0.03 \mathrm{~N} \mathrm{NaOH}$ to a faint pink end-point ( $\mathrm{pH} 8.3$ ).

\section{In Situ Digestibility}

The same three rumen cannulated goats were fed Napier grass and RTP-concentrate mixtures (0\% RTP, $50 \%$ RTP and $100 \%$ RTP) at $3 \%$ of the live weight on DM basis following a $3 \times 3$ Latin Square Design with period and animal as blocking factors. Each period include an adaptation, incubation, and "wash-out" schedule at 1-10, 11-12, and 13-19 days, respectively. Approximately $2 \mathrm{~g}$ of each of RTP-concentrate mixtures were weighed in duplicates and placed in nylon bags (Orskov et al., 1980; Isah \& Babyemi, 2010). RTP concentrate mixtures were incubated to the corresponding goats fed with the same concentrate mixture. The bags were $5 \times 13 \mathrm{~cm}$ in size, with a pore size of $41 \mu \mathrm{m}$. The bags were inserted via permanent ruminal cannulae in 3 native goats and left in the rumen for $3,6,12,24,36$, and 48 hours. The animals were fed with Napier grass at 0700 and 1700 hours. The goats had free access to fresh and clean water. At the end of the incubation period, all bags were withdrawn at the same time. Bags were washed under running cold water until the rinse water was clear and then dried in an oven for 48 hours at $70^{\circ} \mathrm{C}$. The dry bags were weighed and dry matter loss was calculated. The post-incubation residual samples were ground in a Wiley Mill with a $1 \mathrm{~mm}$ screen for crude protein determination.

Kinetic parameters of DM and $\mathrm{CP}$ degradations were estimated using the non-linear procedure of GraphPad Prism 7 (GraphPad Software, Inc., 2016) using the model of McDonald (1981):

$$
Y=a+b\left(1-e^{-c t}\right)
$$

Wherein $Y$ is ruminal DM or CP disappearance at time $t, a$ is the readily degraded fraction (\%), $b$ is the slowly degraded fraction (\%), $a+b=$ potentially degradable fraction (\%), c is the degradation rate constant at which $b$ is degraded, $\mathrm{e}=2.71828$ (base of natural logarithm) and $t$ is the time of incubation.

\section{Statistical Analysis}

Average daily gain, average daily feed intake, and feed efficiency were analyzed using the MIXED procedure of SAS University edition (SAS Institute, 2016) . The model included treatment as fixed effect and parameters for growth performance, rumen paramaters, and DM and CP digestibilities as dependent variables. Least square means was calculated for each independent variable. When diet is a significant source of variation, least square means were separated using the $\mathrm{P}$ value differences (PDIFF) option of SAS. Diets without RTP versus with RTPs were tested for contrast in growth performance of goats. Statistical significance and tendencies were set at $P \leq 0.05$.

\section{RESULTS}

\section{Growth Performance of Goats}

Growth parameters of goats fed concentrates with varying RTP inclusion levels were presented in Table 3. Differences in initial weights of goats were not significant in all treatments while final weights tended to be affected by the inlusion levels of RTP. Goats fed 0\% RTP had greater gains and feed intake but had lesser feed efficiency compared to goats fed concentrates with RTP. Forage intake of goats fed 0\% RTP was greater than those fed 50\% RTP. Concentrate intake tended to be affected by inclusion of RTPs. Goats fed 100\% RTP had the same weight gain, feed intake, and feed efficiency with goats fed concentrates with $0 \%$ and $50 \%$ RTP.

\section{Rumen pH and Metabolites}

The rumen $\mathrm{pH}$ before and after feeding, and concentration of rumen metabolites namely volatile

Table 3. Growth performance of Philippine native goats fed concentrates with different inclusion levels of rain tree (Samanea saman) pods (RTP)

\begin{tabular}{|c|c|c|c|c|c|}
\hline \multirow{2}{*}{ Variables } & \multicolumn{3}{|c|}{ Treatments } & \multicolumn{2}{|c|}{ P-value } \\
\hline & $0 \%$ RTP & $50 \%$ RTP & $100 \%$ RTP & $0 \%$ RTP vs RTPs & Treatment \\
\hline Inittial wgt, (kg) & $8.00 \pm 0.48$ & $6.70 \pm 0.59$ & $6.82 \pm 0.48$ & 0.065 & 0.169 \\
\hline Final wgt, (kg) & $9.31 \pm 0.54$ & $7.42 \pm 0.66$ & $7.31 \pm 0.54$ & 0.015 & 0.041 \\
\hline Total wgt gain, (kg) & $1.21 \pm 0.10^{\mathrm{a}}$ & $0.72 \pm 0.10^{\mathrm{b}}$ & $0.84 \pm 0.10^{\mathrm{ab}}$ & 0.006 & 0.017 \\
\hline Daily gain, $(\mathrm{g})$ & $18.69 \pm 1.59^{a}$ & $10.36 \pm 1.94^{b}$ & $12.52 \pm 2.24^{\mathrm{ab}}$ & 0.008 & 0.018 \\
\hline \multicolumn{6}{|c|}{ Daily feed intake, (g/day) } \\
\hline Forage intake & $205.41 \pm 11.52^{\mathrm{a}}$ & $143.78 \pm 14.10^{\mathrm{b}}$ & $170.30 \pm 11.52^{\mathrm{ab}}$ & 0.006 & 0.014 \\
\hline Concentrate intake & $123.52 \pm 6.58$ & $107.57 \pm 8.06$ & $100.24 \pm 6.58$ & 0.036 & 0.073 \\
\hline Total Feed intake & $328.93 \pm 16.05^{\mathrm{a}}$ & $251.35 \pm 19.66^{\mathrm{b}}$ & $270.54 \pm 16.05^{\mathrm{ab}}$ & 0.018 & 0.018 \\
\hline Feed efficiency ${ }^{1}$ & $18.13 \pm 1.34^{\mathrm{b}}$ & $24.46 \pm 1.64^{\mathrm{a}}$ & $21.74 \pm 1.89^{\mathrm{ab}}$ & 0.039 & 0.039 \\
\hline
\end{tabular}

Note: Means in the same row with different superscripts differ significantly $(\mathrm{P}<0.05) .{ }^{1}$ Feed efficiency computed as $g$ of feeds/ g of gain. 
fatty acid and ammonia were presented in Table 4 . The rumen $\mathrm{pH}$ of goats fed concentrate with or without RTP did not differ among treatments before feeding. However there was a significant decrease in rumen $\mathrm{pH}$ in goats after feeding. Goats fed concentrate with 50\% RTP had lower rumen $\mathrm{pH}$ than goats fed concentrates with $0 \%$ RTP after feeding. Moreover rumen $\mathrm{pH}$ of goats fed $100 \%$ RTP were the same in goats fed concentrates with $0 \%$ and $50 \%$ RTP. Total volatile fatty acids (VFA) and ammonia concentration in goats did not differ significantly among treatments. Concentrations of VFA in goats in this study ranged from 81.60 to $124.80 \mathrm{mg} / \mathrm{L}$ while ammonia ranged from 163.75 to $210.84 \mathrm{mg} / \mathrm{L}$.

\section{In Situ Dry Matter and Crude Protein Digestibility}

In situ rumen $\mathrm{DM}$ and $\mathrm{CP}$ digestibility in goats were presented in Table 5. Concentrate mixture without RTPs had higher values for slowly degradable DM in than in concentrate mixture containing 50 and $100 \%$ RTP. Degradable fractions of CP had the highest value on concentrate mixture without RTP while the lowest

Table 4. Least square means of rumen metabolites of Philippine native goats as affected by different levels of rain tree (Samanea saman) pods (RTP)

\begin{tabular}{lccccc}
\hline \multirow{1}{*}{$\begin{array}{c}\text { Ruminal } \\
\text { parameters }\end{array}$} & $\begin{array}{c}0 \% \\
\text { RTP }\end{array}$ & $\begin{array}{c}50 \% \\
\text { RTP }\end{array}$ & $\begin{array}{c}100 \% \\
\text { RTP }\end{array}$ & MSE & $\begin{array}{c}\text { P- } \\
\text { value }\end{array}$ \\
\hline $\begin{array}{l}\text { Rumen pH } \\
\text { before feeding }\end{array}$ & 6.88 & 6.89 & 7.34 & 0.17 & 0.301 \\
$\begin{array}{l}\text { Rumen pH after } \\
\text { feeding }\end{array}$ & $6.83^{\mathrm{a}}$ & $6.11^{\mathrm{b}}$ & $6.43^{\mathrm{ab}}$ & 0.06 & 0.023 \\
$\begin{array}{l}\text { Volatile fatty } \\
\text { acid (mg/L) }\end{array}$ & 124.80 & 85.20 & 81.60 & 32.00 & 0.614 \\
$\begin{array}{l}\text { Ammonia } \\
\text { concentration } \\
\text { (mg/L) }\end{array}$ & 181.81 & 163.75 & 210.84 & 29.99 & 0.64 \\
\hline
\end{tabular}

Note: Means in the same row with different superscripts differ significantly $(\mathrm{P}<0.05)$. on $100 \%$ RTP. However, no differences were observed on potentially digestible fractions and degradability constant of DM and CP.

\section{DISCUSSION}

\section{Growth Performance of Goats}

It was observed by Barcelo et al. (2003) that goats fed with $100 \%$ rain tree pods had the lowest gain in weight. However, in this study, goats fed concentrate with 50\% RTP had the lowest total weight gain. Albino rats fed 30\% RTP were found to have the highest weight gain compared to rats fed 0\% RTPs (Idowu et al. 2006). Bali cattle fed rain tree foliage supplemented with rice bran, copra meal, or Gliricidia to the basal diets resulted in increased body weight gain from 0.225 to $0.402 \mathrm{~kg} /$ day (Marsetyo et al., 2011).

Lower feed intake of goats fed RTP was probably due to tannin content of RTP. Tannin can bind with proteins in the mouth reducing the palatability of the feed and subsequently decreases feed intake (Cheema et al., 2011). Reduced feed intake of forage legumes are usually due to tannins that affect palatability (Krebs et al., 2007; Provenza et al., 2000).

The nutritive value of RTP was observed to be equivalent to cereal grain byproducts such as deoiled rice bran. Rain tree pods can be incorporated in the diet of ruminants as replacement for concentates to reduce feed cost (Hosamani et al., 2004). Anantasook \& Wanapat (2011) observed that RTP can be a potential supplement for improving rumen fermentation.

\section{Rumen $\mathrm{pH}$ and Metabolites of Goats}

The rumen $\mathrm{pH}$ dereased in goats fed 50\% RTP after feeding. Rumen $\mathrm{pH}$ decreases with increasing crude protein levels in the diet (Mathis et al., 2000). Changes in $\mathrm{pH}$ are results of changes in ruminal fermentation wherein protein content in the diet may affect ruminal fermentation (Chen et al., 2010).

Total volatile fatty acid for all treatments ranged from 81.60 to $124.80 \mathrm{mg} / \mathrm{L}$ (Table 4). Anantasook \&

Table 5. Rumen degradation characteristics for dry matter (DM) and crude protein (CP) of different levels of rain tree (Samanea saman) pods (RTP) in Philippine native goats

\begin{tabular}{|c|c|c|c|c|c|}
\hline \multirow{2}{*}{ Digestibility, (\%) } & \multicolumn{3}{|c|}{ Treatments } & \multirow{2}{*}{ MSE } & \multirow{2}{*}{ P-value } \\
\hline & $0 \%$ RTP & $50 \%$ RTP & $100 \%$ RTP & & \\
\hline \multicolumn{6}{|l|}{ Dry matter } \\
\hline Readily degradble & 38.67 & 48.33 & 49.33 & 2.41 & 0.14 \\
\hline Slowly degradable & $30.00^{a}$ & $21.00^{\mathrm{b}}$ & $17.33^{\mathrm{b}}$ & 0.51 & 0.003 \\
\hline Potentially degradable & 74.67 & 69.33 & 66.67 & 2.8 & 0.32 \\
\hline Degradation constant & 0.07 & 0.07 & 0.07 & 0.02 & 0.99 \\
\hline \multicolumn{6}{|l|}{ Crude protein } \\
\hline Readily degradble & $12.67^{a}$ & $28.33^{\mathrm{ab}}$ & $48.33^{\mathrm{b}}$ & 3.47 & 0.04 \\
\hline Slowly degradable & $57.67^{a}$ & $37.00^{\mathrm{ab}}$ & $18.67^{b}$ & 4.07 & 0.04 \\
\hline Potentially degradable & 70.33 & 65.33 & 67 & 0.69 & 0.07 \\
\hline Degradation constant & 0.04 & 0.09 & 0.1 & 0.03 & 0.35 \\
\hline
\end{tabular}

Note: Means in the same row with different superscripts differ significantly $(\mathrm{P}<0.05)$. MSE= Standard error of means. 
Wanapat (2011) found that interaction of roughage to concentrate and RTP inclusion in diets significantly increased total volatile fatty acid and propionate concentration, whereas it lowered acetate, acetate to propionate ratios, and methane $\left(\mathrm{CH}_{4}\right)$ production. Moreover, Ruiz et al. (2004) observed an increase total VFA concentration reflecting a stimulated microbial activity.The fiber in the diet can also influence VFA concentration in the rumen wherein fiber hydrolysis are one of the sources of energy for microbial growth in the rumen. Fiber degradation at low $\mathrm{pH}$ can be used to predict VFA production (Djikstra et al., 2012).

Estimates of the rumen ammonia concentration required for optimal microbial fermentation and growth in the rumen vary (Chantai et al., 1987) where in the ammonia pool in the rumen are coming from both dietary and endogenous sources which would include the degradation of endogenous urea as well as the assimilation of urea by microorganisms and absorption and removal of ammonia in digesta (Darlis et al., 2000).

Ammonia levels can be affected by supplementation in the diets which may alter the ratio of protein and carbohydrates in the diet. A diet reach in soluble carbohydrates decreases the concentration of ammonia in the rumen (Philippson, 1970). Additional carbohydrate sources may result in better synchrony of energy and ammonia-N for microbial protein synthesis (Darlis et al., 2000). Ruminal ammonia N concentrations were generally lower in goats than in sheep (Ruiz et al., 2004) although in both animal species, values were within the range (5.90 to $12.0 \mathrm{mg} / 100 \mathrm{~mL}$ ) indicating an optimal microbial activity.

\section{In Situ Dry Matter and Crude Protein Digestibility}

Lower slowly degradable DM in diets containing RTP maybe due to the nature of structural and functional components of the pod. It is naturally rich with bioactive compounds intended to protect the seed from pests. CP fraction of RTP are likewise poorly unavailable as suggested by the decreasing slowly degradable values as RTP is increased in the diet. Tannins in RTP is at $40 \mathrm{~g} / \mathrm{kg}$, hence, might have caused detrimental effects on microbial activity in the rumen (Staple \& Elvitch, 2006).

In sacco losses of protein may not necessarily correlate with degradability when applied to tanniferous feeds because part of the protein loss from the nylon bags may be in the form of tannin-protein complexes which are not degradable in the rumen (Nsahlai et al., 1999; McNabb et al., 1996; Perez-Maldonado \& Norton, 1996) hence, reducing the protein availability to rumen microbes (Ngwa et al., 2001). Crude protein in diets results in increased ruminal ammonia nitrogen concentration. Increased ruminal ammonia nitrogen enhances microbial activity and growth, resulting in greater dry matter digestibility (Cheema et al., 2011).

Lower degradation values of $\mathrm{CP}$ in concentrates with RTP may be due to the other anti-nutritional factors normally contained in leguminous pods which are known to be detrimental to rumen microbial population and consequently the host animal (Ngwa et al., 2001).
The constant of degradation rate for DM and $\mathrm{CP}$ were the same in goats. Moreover, the rate of digestion of rain tree pods $(0.07 \%)$ for DM was lower than the rate of digestion of Leucaena leucocephala (0.16\%) after cross inoculation as reported by Pamungkas et al. (2005). In contrast, the rate of digestion of rain tree pods $(0.10 \%)$ for $\mathrm{CP}$ was higher than the rate of digestion of Leucaena leucocephala $(0.03 \%)$ as reported by Sevilla \& Purbojo (2005).

\section{CONCLUSION}

Gain, feed intake, feed efficiency as well as rumen $\mathrm{pH}$ were affected by the presence of RTP in concentrate mixture while VFA and ammonia concentrations in the rumen were not influenced by treatments. Generally, slowly degradable DM and CP portions in concentrate mixture with increasing level of RTP. Rain tree pods can be used as source of nutrients for goats at 50\% RTP in the concentrate mixture for goats. Feeding trial and in situ study are considered useful indicators for the evaluation of the nutritive value of the particular feed. Antinutritional factors in RTP should be further evaluated in order to know the extent of inclusion of RTP in animal feeds and determine the potential feed processing for optimum nutrient utilization.

\section{ACKNOWLEDGEMENT}

The authors wish to acknowledge the financial support by the Deutscher Akademischer Austausch Dienst (DAAD) - German Academic Exchange Service, and Southeast Asian Regional Center for Graduate Study and Research in Agriculture (SEARCA).

\section{REFERENCES}

Anantasook, N., \& M. Wanapat. 2011. Influence of rain tree pod meal supplementation on rice straw based diets using in vitro gas fermentation technique. Asian-Aust. J. Anim. Sci. 25: $325-334$

AOAC. 2005. Official Methods of Analysis of AOAC International. 18th ed. Assoc. Off. Anal. Chem., Arlington.

Attoh-Kotoku, V. 2011. Feeding two nerica rice straw varieties to sheep: effects of supplementation with leguminous foliages on digestibility, nutrient utilization and growth performance. College of Agriculture and Natural Resources. Retrieved on 29 December 2016 from http://ir.knust.edu. gh/handle/123456789/2090.

Barcelo, P.M., Ungria, J., \& Fabro, A. 2003. The potential of acacia (Samanea saman) pods as feeds for goats. Research Journal - Agriculture Department Don Mariano Marcos Memorial State University (DMMMSU). http://agris.fao. org/agris-search/search/display.do?f=2006/PH/PH0605. xml;PH2006M00021, 13 April 2011.

Berhan, T. \& A. Getachew. 2009. Effects of different forms of Acacia saligna leaves inclusion on feed intake, digestibility and body weight gain in lambs fed grass hay basal diet. Anim. Feed Sci.Technol. 153: 39-47. https://doi. org/10.1016/j.anifeedsci.2009.05.010

Chantai, S., M. Wanapat, \& C. Wachirapakorn. 1987. Rumen ammonia- $\mathrm{N}$ and volatile fatty acid concentrations in cattle and buffalo given rice straw based diets. Proceedings of the seventh annual workshop of the Australian-Asian fibrous agricultural residues research network. Chiang Mai 
University, Thailand.

Cheema, U.B., J.I. Sultan, A. Javaid, P. Akhtar, \& M. Shahid. 2011. Chemical composition, mineral profile and in situ digestion kinetics of fodder leaves of four native trees. Pak. J. Bot. 43: 397-404.

Chen, S., P. Paengkoum, X. Xia, \& P. Na-Lumpang. 2010. Effects of dietary protein on ruminal fermentation, nitrogen utilization and crude protein maintenance in growing Thai-indigenous beef cattle fed rice straw as roughage. Journal of Animal and Veterinary Advances. 9: 2396- 2400. https://doi.org/10.3923/javaa.2010.2396.2400

Darlis, N., R.A. Abdullah, S. Halim, S. Jalaludin \& Y.W. Ho. 2000. Rumen Paramters and Urea Kinetics in Goats and Sheep. Asian-Australas. J. Anim. Sci. 13: 922-928. https:// doi.org/10.5713/ajas.2000.922

Darlis, N., R.A. Abdullah, S. Jalaludin \& Y.W. Ho. 2000. Effects of protein and carbohydrate supplements on feed digestion in indigenous Malaysian goats and sheep. AsianAustralas. J. Anim. Sci. 13: 464- 469. https://doi.org/10.5713/ ajas.2000.464

Delgado, D.C., R. Hera, J. Cairo \& Y. Orta. 2014. Samanea saman, a multi-purpose tree with potentialities as alternatve feed for animals of productive interest. Cuban J. Agr. Sci. 48: 205- 212.

Djikstra, J., J.L. Ellis, E. Kebreab, A.B. Strathe, S. Lopez, J. France, \& A. Bannink. 2012. Ruminal pH regulation and nutritional consequences of low $\mathrm{pH}$. Anim. Feed Sci. Technol. 172: 22-33. https://doi.org/10.1016/j. anifeedsci.2011.12.005

Flores, E.M. 2002. Samanea saman (Jacq.) Merr. In: J.A. Vozzo (ed.) Tropical Tree Seed Manual. Agriculture Handbook 721. USDA Forest Service, Washington, DC.

Graphpad Software Inc. 1999. San Diego CA.

Hagan, M.A.S., D. Armstrong, \& A. Dadson. 2016. Growth performance and economic evaluation of broiler Chicken fed with rain tree (Samanea saman) seed meal. Cogent Food \& Agriculture 2: 1277445. https://doi.org/10.1080/2331193 2.2016.1277445

Holtshausen, L. \& C.W. Cruywagen. 2000. The effect of age on in sacco estimates of rumen dry matter and crude protein degradability in veal calves. S. Afr. J. Anim. Sci. 30: 212219. https://doi.org/10.4314/sajas.v30i3.3854

Hosamani, S.V., N.K.S. Gowda, \& S.D. Kololgi. 2004. Evaluation of chemical, nutritive and feeding value of rain tree pods. Karnataka J. Agric. Sci., $18: 110-113$.

Idowu, A.B., O.D. Babalola, \& K.O Ademolu. 2006. The physiological impact on the consumption of Albizia saman pods by albino rats. J. Anim. Vet. Adv. 5: 585-589.

Isah, O.A. \& O.J. Babyemi. 2010. Nutrient degradability and performance by the West African Dwarf goats fed rumen epithelium-based diets. J. Agr. Sci. Tech. 12: 289-297.

Kriaa, S., A. Thewis, \& M. Kamoun. 1999. Les tannins en nutrition animale, effet des tannins sur l'ingestion, la digestibilité et les performances des ruminants. Revue de l'I.N.A.T. Vol. 14 no 2 - Décember 1999. ISSN 0330 - 8065.

Krebs, G.L., D.M. Howard, \& K. Dods. 2007. The effects of feeding Acacia saligna on feed intake, nitrogen balance and rumen metabolism in sheep. Asian-Australas. J. Anim. Sci. 20: 1367-1373. https://doi.org/10.5713/ajas.2007.1367

Kumara-Mahipala, M.B.P., G.L. Krebs, P. McCafferty \& L.H.P. Gunaratne. 2009. Chemical composition,biological effects of tannin and in vitro nutritive value of selected browse species grown in the West Australian Mediterranean environment. Anim. Feed Sci. Technol. 153: 203-215. https:// doi.org/10.1016/j.anifeedsci.2009.06.014

Marsetyo, D., S.P. Quigley, S.R. Mclennan \& D.P. Poppi. 2012. Live weight gain and feed intake of weaned Bali cattle fed a range of diets in Central Sulawesi, Indonesia. Anim.
Prod. Sci. 52: 630- 635.

Mathis C.P., R.C. Cochran, J.S. Heldt, B.C. Woods, I.E Abdelgadir, K.C. Olson, E.C.Titgemeyer \& E.S. Vanzant. 2000. Effects of supplemental degradable intake protein on utilization of medium- to low-quality forages J. Anim. Sci. 78: 224-232. https://doi.org/10.2527/2000.781224x

McDonald, I. 1981. A revised model for the estimation of protein degradability in the rumen. J. Agric. Sci. Camb. 96:251-252.

McNabb, W.C., C.C. Waghorn, J.C. Peters \& T.N. Barry. 1996. The effect of condensed tannins in Lotus pendunculatus on the solubilization and degradation of ribulose-1,5-biphosphate carboxylase (EC 4.1.1.139; Rubisco) protein in the rumen and site of Rubisco digestion. Br. J. Nutr. 76: 535-549. https://doi.org/10.1079/BJN19960061

Mokoboki, H.K., L.R. Ndlovu \& M.M. Malatje. 2011.Intake and relative palatability indices of acacia species fed to sheep and goats. Agrofor. Syst. 81: 31-35. https://doi. org/10.1007/s10457-010-9352-5

Ngwa, A.T., I.V. Nsahlai \& M.L.K. Bonsi. 2001. The rumen digestion of dry matter, nitrogen and cell wall constituents of the pods of Leucaena leucocephala and some Acacia species. J. Sci. Food. Agric. 82: 98-106. https://doi.org/10.1002/ jsfa.1008

Nsahlai, I.V., N.N. Umunna \& P.O. Osuji. 1999. Influence of feeding sheep on oil seed cake following the consumption of tanniferous feeds. Livestock Prod. Sci. 60: 59-59. https:// doi.org/10.1016/S0301-6226(99)00036-6

Nyamukanza, C.C., \& P.F. Scogings. 2008. Sprout selection and performance of goats fed Acacia karroo coppices in the False Thornveld of the Eastern Cape, South Africa. S. Afr. J. Anim. Sci. 38: 83-90.

Olivares, P.J., N.F. Aviles, P.B. Albarran, O.O.A. Castelan, \& H.S. Rojas. 2013.Use of three fodder trees in the feeding of goats in the sub humid tropics in Mexico.Trop. Anim. Health Prod. 45: 821-828. https://doi.org/10.1007/ s11250-012-0294-y

Orskov, E.R., F.D.D. Hovell, \& F. Mould. 1980. The use of nylon bag technique for the evaluation of feedstuffs. Trop. Anim. Prod. 5: 195-213.

Ørskov, E. R. \& I. Mcdonald. 1979. The estimation of protein degradability in the rumen from incubation measurements weighted according to rate of passage. J. Agric.Sci. 92:499503. https://doi.org/10.1017/S0021859600063048

Pamungkas, D., C.C. Sevilla, \& U.M. Lustria. 2005. Changes in rumen ecosystem and feed dry matter degradability of buffalo which received rumen content of cattle through cross inoculation. JITV 11: 24-33.

Perez-Maldonado, R.A. \& B.W. Norton. 1996. Digestion of ${ }^{14}$ Clabelled condensed tannins from Desmodium intortum in sheep and goats. Br. J. Nutr. 76: 501-513. https://doi. org/10.1079/BJN19960059

Philipson, A.T. 1970. Ruminant Digestion. In: Dukes Physiology of Domestic Animals (Ed. M.J. Swenson) Cornell University Press, Ithaca and Canada. pp 424-483.

Provenza, F.D., E.A. Burritt, A. Perevolotsky, \& N. Silanikove. 2000. Self-regulation of intake of polyethylene glycol by sheep fed diets varying in tannin concentrations. Department of Rengeland Resources, Utah State University, Logan, Israel.

Rath S. C., K. C. Nayak, K. N. Mohanta, C. Pradhan, P. V. Rangacharyulu, S. Sarkar, \& S. S. Giri. 2014. Nutritional evaluation of rain tree (Samanea saman) pod and its incorporation in the diet of rohu (Labeo rohita Hamilton) larvae as a non-conventional feed ingredient. Indian J. Fish., 61:105-111.

Rojas, H.S., N.F. Aviles, O.O. Castelan, M.A. Garcia, P.J. Olivares, \& A.M.T. Valencia. 2012. Chemical composition, in vitro digestibility of foliage Guazuma ulmifolia and 
Crescentia alata and its use in feeding lambs. Pak. J. Nutr. 11: 1139-1145. https://doi.org/10.3923/pjn.2012.1139.1145

Ruiz, D.R.Y., A. Moumen, A.I. Martin Garcia, \& E. Molina Alcaide. 2004. Ruminal fermentation and degradation patterns, protozoa population, and urinary purine derivatives excretion in goats and wethers fed diets based on twostage olive cake: effect of PEG supply. J. Anim. Sci. 2004. 82:2023-2032. https://doi.org/10.2527/2004.8272023x

SAS ${ }^{\circledR}$ University Edition. 2016. SAS Institute Inc., Cary, NC.

Sevilla, C.C., \& S.W. Purbojo. 2005. Addition of mimosa tannin protected the protein in gliricidia (Gliricidia sepium) from rumen microbial degradation. Philippine J. Vet. Anim. Sci. 31:29-36.
Staples, W. G. \& R.C. Elevitch, R. C. 2006. Samanea saman (rain tree), ver 2.1. In R. C., Elevitch (Ed.), Species profile for Pacific Island agroforestry (pp. 2-7). Holualoa, HI: Permanent Agriculture Resources (PAR).

Van Soest, P.J. \& J. B. Robertson. 1985. Methods of analysis of dietary neural detergent fiber and non-starch polysaccharides in relation to animal nutrition. J. Dairy Sci. 74: 3585-3597. 